\title{
Digitising Newspaper Content in Indonesia: The Challenge of Enforcing the Culture of Immediacy
}

\author{
AMBANG PRIYONGGO \\ HAMEDI MOHD ADNAN \\ University of Malaya
}

\begin{abstract}
This research is aimed at examining how the culture of immediacy is implemented in a newspaper undergoing digital transformation. This paper is written based on the case of Harian Kompas, the most influential newspaper in Indonesia, that just officially launched its paywall-based digital site, kompas.id as an alternative platform. Within this context, the daily implemented the digital-first strategy to put the priority of rapid digital news production prior to its slow-pace print edition. Through ethnography fieldwork in the daily's newsroom, relying on in-depth interviews and participant observations, the study highlights a notion that the culture of immediacy is not easy to implement. The challenge rests on the fact that it is not only contradictory to the common rhythm of rigid newspaper work-flow and deadline among reporters and editors, but further it is considered harmful to the daily's prescribed core value of comprehensive journalism originated from its editorial philosophy as well as journalism credo of being credible. It is within the constant negotiations among all the newsroom's actors, the culture of immediacy remains to be a contesting value that should be carried out by the daily as a way to excrete the old habit of print deadline while the digital-first transformation is still taking shape.
\end{abstract}

Keywords: Immediacy, digital-first, digital journalism, news production, digital transformation.

\section{INTRODUCTION}

Digital technology with its current wide range of features that include computers, mobile devices, multimedia instruments, software and applications, and social network, together with communication technology, such as satellite and fiber-optic, have created a digitalised society. This certainly brings profound impact in the context of journalism as well, from the use of various digital tools to help journalists in covering the news, to larger aspects of news production and distribution of multiplatform contents through convergent system with the emergence of new actors like programmers, citizen journalists, or even machine algorithms (Tong \& Lo, 2017). Moreover, since digital technology has also brought a huge shift of the speed and exchange of information, it has resulted in the culture of immediacy as the most common feature for journalism (Usher, 2014).

In the context of journalists working in the digital environment, immediacy has never been so important than before. It is aimed at disseminating information quickly, with no lag between fresh content gathered and produced by news producers to be passed on to audiences or news consumers (Karlsson, 2007; Lim, 2012; Omar, 2017). At its initial stage, during the early adoption of digital technology by conventional media like newspapers, the ability to update the website was considered to be a defining characteristic of online news as compared to traditional media (Domingo, 2008). Notwithstanding such potentials, however, the primacy of immediacy was implemented in a rather modest way, especially to transmit breaking news. This is due to the dependency on the traditional media (print/newspaper) that mainly posed as the editorial backbone. Immediacy was then implemented even more to 
disseminate current events and other useful services to audiences as journalists tried to publish their stories as soon as possible, and wire services (news agencies) were considered to be very useful resources of news.

The immediacy has even massively transformed as an inevitable feature for digital journalism due to the further development of new media technology with its more networked information environment. In fact, immediacy has become a key determining differentiator of digital news production as compared to conventional journalism practices, in the sense that the accelerated pace and speed of reporting has become inevitable (Zeller \& Hermida, 2015). Departing from the remark of Manuel Castells (2009) that the high communication technology has brought a huge shift on the speed and exchange of information, Usher (2014) points out its interrelation with the spheres of commerce, social life, and politics that eventually create the all times demand of access to informations. Accordingly, in the context of immediacy in digital journalism, this would bring substantial effect. As Usher further reveals, the deadline of all news rooms became "now" and eventually created not only competition (in a sense of differentiation) among news organisations, but also big efforts to make use of the potential of social media sites not only as a platform to gather and discuss news, but also the paramount source for newsbreak. Elsewhere, Usher (2017) also argues that the power of immediacy has evidently become news value in which it is influential on the decision making among journalists as well as journalism quality.

Although there is much appreciation on the tendency that culture of immediacy has become part of digital news organisation, several studies revealed the constraints of its content implementation. Immediacy would mean that abrupt, incomplete and even dubious news drafts are transmitted to the public (Karlsson, 2011). It was also considered to potentially displace the ideal type of in depth reporting within day-to-day routines of journalists who focus more on speed rather than deepness and cause difficulties to deal with interactivity (Domingo, 2008). Moreover, implementing culture of immediacy, especially for a newspaper undergoing digital transformation, will potentially result in laid-bare or mistake of journalism process as news is produced before it is ready in the radically shrunken time between production and distribution of news (Usher, 2014).

Immediacy-together with interactivity and participation-has been the branches of digital journalism that are widely studied, especially within the Western context. While most of those studies have been contributive towards the overall study of journalism, further empirical inquiries need to be done, noting the fact that the intertwining of digital technology and journalism is very dynamic, especially with the current feature of social networks and changing-role of audiences.

This paper focuses within the context of Indonesia, departing from the fundamental approach of the impact of the latest digital technology on journalism practices that has never been done before. Aiming at examining how the culture of immediacy is implemented in a newspaper undergoing digital transformation, Harian Kompas, the country's most influential daily newspaper, was chosen as a setting for this study. The selection of the daily was done due to the fact that it is the country's pioneer to implement a digital-first transformation, putting priority on its newly launched and paywall-based kompas.id through rapid digital news production prior to its slow pace print edition. 


\section{LITERATURE REVIEW}

\section{Content Digitisation in Indonesian Media Landscape}

Digitisation is an important part of the development of journalism practices in Indonesia since the introduction of the Internet technology in the country in the mid-1990s (Sen \& Hill, 2000/2007; Lim, 2005). Defined as the process of conversion of analogue data into digital form (Schumacher, Sihn, \& Erol, 2016), digitisation within the journalism world was notable as some mainstream newspapers adapted Internet technology as a new platform to deliver their print content online.

The first newspaper that launched its website version was Republika (www.republika.co.id) in August 1995, followed by Kompas (www.kompas.co.id) in September 1995, Tempo Interaktif Magazine in March 1996 (two years after its printed edition was shut down by the government for being too critical), and Bisnis Indonesia in September 1996 (Sen \& Hill, 2000/2007; Margianto, 2017). Since the technology was mere web 1.0, most of the media only recycled the content they had in the printed edition-except Tempo, which only had an alternative platform via online heeding to the government restriction to print. It was the arrival of detik.com, an online media founded in July 1998, just after the downfall of the authoritarian regime of Soeharto, that marked the beginning of what is now, a highly crowded Indonesian news space (Anggoro, 2012; Tapsell, 2017).

Now, under relatively stable and consolidated democracy, the evolution of online journalism continues to unfold, with an estimated number reaching more than 43,000 outlets (Manan, 2018). Overall, the mainstream media companies in Indonesia have responded to digitalisation by making rapid and extensive adaptations. With the increasing level of concentration and oligopolistic nature within the mainstream media industry under the uncertain digital era, expanding the platforms, audience, and readership reach were believed by the media owners and executives to be the best way to survive (Tapsell, 2017).

While Manan (2018) admitted that digitisation has introduced convergence, and many print-based media organisations try to expand to multiplatform, it does not really help them to sustain its existence. In fact, he argued that "the digital explosion" should be held responsible for the sunset of the print media industry that eventually causes concerns on media resources issues. Data from the Union of Print Media Company (SPS) quoted in the 2018 Independent Journalist Alliance (AJI) Report has evidently shown the gradual and slight decline of print media since 2011 to 2014. Yet, the significant decrease started in 2015 as the figure touched to merely 1,218 publications from the previous year's figure of 1,321 . The eroding number of print media kept going within the next two years as the figure reached 810 publications in 2016 and 793 publications in 2017 (Manan, 2018, p. 56-57).

Table 1: Declining Trend of Print Media (Manan, 2018)

\begin{tabular}{cccccccc}
\hline Year & $\mathbf{2 0 1 1}$ & $\mathbf{2 0 1 2}$ & $\mathbf{2 0 1 3}$ & $\mathbf{2 0 1 4}$ & $\mathbf{2 0 1 5}$ & $\mathbf{2 0 1 6}$ & $\mathbf{2 0 1 7}$ \\
\hline Figure & 1,361 & 1,324 & 1,254 & 1,321 & 1,218 & 810 & 793 \\
\hline
\end{tabular}

AJI Report also reveals that the decrease happened to all types of print media, ranging from daily newspaper, weekly newspaper, tabloid and magazine. However, the data show the most plummeting figures hit weekly newspapers, from 2,002 publications in 2015 to merely 67 in 2017. Similarly, magazine figures also plunged drastically, from 420 publications in 2015 to become 134 in 2016 and eventually went to 133 in 2017. 
Table 2: Number of Print Media (Manan, 2018)

\begin{tabular}{lccccccc}
\hline Types & $\mathbf{2 0 1 1}$ & $\mathbf{2 0 1 2}$ & $\mathbf{2 0 1 3}$ & $\mathbf{2 0 1 4}$ & $\mathbf{2 0 1 5}$ & $\mathbf{2 0 1 6}$ & $\mathbf{2 0 1 7}$ \\
\hline Daily Newspaper & 401 & 400 & 394 & 418 & 383 & 400 & 399 \\
Weekly Newspaper & 284 & 230 & 220 & 218 & 202 & 67 & 67 \\
Magazine & 411 & 455 & 421 & 449 & 420 & 209 & 194 \\
Tabloid & 265 & 239 & 219 & 236 & 213 & 134 & 133 \\
Total & 1,362 & 1,324 & 1,254 & 1,321 & 1,218 & 810 & 793 \\
\hline
\end{tabular}

All of the figures presented above indicate that the print media industry has been experiencing trouble to keep its business existence. Manan (2018: 60) argues that there are at least two reasons behind this phenomenon: declining readers and declining advertising. In fact, the 2017 survey on Nielsen Consumer Media Viewing in 11 big cities indicates that the dominant medium for Indonesian audience is still dominated by television (96\%), outdoor (53\%), Internet (44\%) and radio (37\%). Meanwhile the least medium viewed is newspaper (7\%) and magazine and tabloid (3\%). As the number of internet penetration reached $44 \%$, Nielsen points out that this implies Indonesians' preference on accessing contents through digital media rather than conventional print media (Lubis, 2017).

\section{The Culture of Immediacy as Part of Digital Technology Adaptations}

Most of the studies on immediacy under consideration of technological change are focusing within two lines of research. The first line takes on the process of production approach, revealing various factors from technical editorial, institutional, or competitive rivalry among news outlets as the driving forces behind the speedy production process (e.g. Domingo, 2008; Karlsson, 2011; Lim, 2011; Usher, 2014). The second line of research focuses on the output of the practice of immediacy by closely examining the contents. Lewis, Cushion, and James (2005), Boczkowski (2010), Saltzis (2012), together with Buhl, Günther, and Quandt (2019) relied on content analysis to explore how and what types of the news update are treated and managed within time constraints. Still on the issue of content, Boczkowski (2004) as well as Omar (2017), coining remediation perspective, argue on the importance of creating media products that generate the experience of being there for users when they interact with the news content and the medium.

Other works on immediacy even try to move beyond the approach of technological change. A work done by Usher (2017) put forward discussion of immediacy by connecting it to the professional authority of journalists. Further discussions of immediacy have even taken to the next level of inquiries as Fink and Schudson (2014) brought a new perspective on contextual journalism, a style of journalism disregarding the need of speedy reporting. Another work by Le Masurier (2015) brings forward the notion of slow journalism that has deleterious effects of speed in news production.

While the works of immediacy under the perspective of technological change and beyond are abundant, especially in the Western context, it has not been the focus of scholars who examine digital technology and media in Indonesia. Most of the focuses of the research are on digital media and their intersection with culture and politics (Lim, 2005; Hill \& Sen, 2005, 2011). Other seminal studies like those done by Sudibyo (2014), Lim (2011, 2012), Nugroho, Putri and Laksmi (2012), and also Tapsell $(2014,2017)$ focus more in a wider scope of ownership and the political economy of the digital media within the context of public 
sphere and democracy. This points out the need to fill-in the gap, by proposing a fundamental approach of technological change within the context to study the practice of immediacy by Indonesian media.

\section{METHODOLOGY}

This study implemented newsroom ethnography fieldwork at Kompas' newsroom for nearly six months, between November 2018 to May 2019, spending between six to eight hours a day, three to four days a week at Kompas' headquarters at Jakarta. A preliminary visit was done in March 2018 for getting some contextual backgrounds, physical setting, and census information for determining potential participants. During this phase, four informants were identified as gatekeepers, key persons that helped to begin the ethnography (Crang \& Cook, 2007). The newsroom social setting required certain procedures to be followed and depended on a few journalists who became our gatekeepers. In the sense of snowballing, as the fieldwork progressed, we then expanded from there to other participants. There were a total of 20 informants, ranging from editors to reporters, involved in this ethnography.

While most ethnographic studies dominantly use informal interviews (Fetterman, 2010), this research uses the approach with the main purpose to discover what the informants' think, and eventually exploring their perceptions on the implementation of culture of immediacy. Semi-structured interviews with pre-determined questions were also deployed for more explicit research goals, especially during the middle and end phases of the fieldworks. All types of interviews were mostly done in one-on-one mode. Small groups of interviews consisting of two informants, however, were sometimes inevitable to implement especially during situations that allowed group contexts and group interactions inside the newsroom.

Observer as participant technique was also used alongside the interviews. The procedure was effective for its flexibility features. As stated by Gobo (2008), the technique enables the ethnographer to establish a direct relationship with the subject by residing in the subjects' natural setting within a certain period of time, to observe and describe their behaviours.

The analysis process in this research implemented inductive coding using the thematic analysis (TA) procedure of Braun and Clarke that include: familiarising with the data, generating initial codes, searching for themes, reviewing the themes, defining and naming the themes, and producing the report (Braun \& Clarke, 2006). All of the data-interviews transcripts, observational notes, and other supportive documents-were analysed using the computer assisted program, NVivo 12.

\section{RESULTS AND DISCUSSION}

In the context of Kompas Daily newsroom, immediacy has shaken up the existing prescribed culture of newspaper routines that is known for its rigid workflow and inflexible deadline. The early weeks of field work at the daily's newsroom revealed that the culture of immediacy had been far from being optimally adapted by the newsroom. Immediacy was in fact not a part of the culture within its online division. The afternoon editorial meeting, held on 27 November 2019, confirmed the notion that the kompas.id sites of the newspaper was initially treated more as a shovel-ware site of the newspaper edition rather than a real-time news online portal, with sporadic updated reportages mainly from its cub reporters on digital desk. What is even more striking being our field observations showed that this digital desk even set up its 
main news agenda that was rather different from its newspaper edition, alerting the fact that the desk was a kind of different entity within a single newsroom.

The editor-in-chief, Ninuk Pambudy, led the editorial meeting consisting of representatives of editors from all desks in the newsroom, including the online division. Each desk editor had a chance to present lists of issues in the meeting forum; receiving feedback on how the issues should be shaped and placed within limited space on its newspaper edition. Almost all of the entire time of the editorial meeting was dedicated to decide what would go for its next day's print edition. The online edition only had around the final five minutes to report its news lists and news agenda without any feedback from the forum. Instead of following where the issues broke out and bounded through on-the-spot reporting, the editor of digital desk listed a rather timeless issue covered by its reporters, including the desk's tomorrow's agenda.

This lack of immediacy seemed to be permissible at that time, as the daily was still in preparation for its official transformation to digital first that commenced on 2 January 2019. However, as this ethnographic immersion in the newsroom was progressing during the early stage of digital first transformation, the challenges to enforce culture of immediacy emerged within the following issues of retaining prescribed print traditions.

\section{Immediacy as a New Deadline Mechanism}

Under digital first policy that was aimed at making the digital platform a core aspect for the entire workflow, blending its print and online, all of the journalists were expected to send in news stories immediately within four hours after the newsbreak. The news should be sent through a CMS bucket called SILO where the editors can decide whether their placement should be online or (later on for) print or even both.

Interviews with the majority of the participants highlighted notions that the constraints of applying the culture of immediacy as a new deadline mechanism resides on the fact that it is against the very nature of journalism style of the daily. Being prominently known for its cautious and polished-style of depth news under what they called as comprehensive journalism, Kompas relies so much on the slow pace of reporting. This style has been the essential character of the daily to be dubbed as both the most credible and influential media in the country.

The founder as well as the first editor-in-chief, Jakob Oetama, defined comprehensive journalism of Kompas as something distinct from factual and interpretative journalism (Oetama, 2001). In factual journalism, an event ' $A$ ' is observed with one-way dimension from the beginning and its continuation; interpretative journalism goes beyond by relating the event ' $A$ ' with other events to become multidimensional. In comprehensive journalism, the event ' $A$ ' is completed not only relating it to multidimensional factors, but further trying to place the event ' $A$ ' to the social system with extended reference frames like system value, political system, economic planning and others. Such style enables Kompas to package a simple event to become important, a very intense event to be more neutral, and a very messy one to become more structured (Priyonggo \& Wijaya, 2013).

This prescribed style is rigidly internalised and carried out as daily working standards among the Kompas' journalists for years. This resulted in difficulties to adjust to the new immediacy culture as preparing comprehensive news would mean taking up longer time. As the deputy managing editor, Haryo Damardono, stated: 
Indeed, it is not easy for us because all journalists at Kompas... they applied for a job position as print journalists, not digital or online ones. Then in our internal training, we were taught not to write stories at a rapid pace but rather in accurate and comprehensive style... Everything should be checked and rechecked. It is our habit that after we cover news, we do not directly write the stories, but rather take time to contemplate, to think (Haryo Damardono, interview, March 2019).

Even for a digital savvy journalist like Antony Lee, who is also an enthusiast of the data journalism community of Journocoders Indonesia, imposing immediacy as a new deadline mechanism was deemed potentially harmful to the very character of the daily. As he put it:

Kompas' elements are unlike rapid journalism, as I would say. Kompas is more like within a slow pace journalism that places every issue in the proper context. If we would like to transform a thing within the digital first, this should be it, as it is actually our difference [to compete with other media] (Antony Lee, interview, February 2019).

Overall, from the elaboration above, the practice of immediacy in Kompas intertwined mostly with its standard, which is conflicting. As a result, this became certain constraints for the daily for its day-to-day digital journalism practices. Such a problematic situation was not due to the ignorance of the editorial executives. They were aware of the fact that immediacy might contradict with the strongly-held print culture of the daily. However, they have made a clear norm that the immediacy type of the daily would not mean sacrificing the journalism standard: accuracy and comprehensiveness.

When asked about the ideal type of immediacy in a print cultural setting, Sutta Dharmasaputra, one of the deputies of editor-in-chief, who was responsible for the digital first transition, could not give a clear-cut definition on the matter since he argued that the transition to a new culture was still taking shape. Instead, he insisted that the immediacy was a kind of new organisational norm enacted in the newsroom as they were trying to meet the digital deadline of fulfilling the high traffic times at 12:00 to $13: 00 \mathrm{pm}$ and 17:00 to $19: 00 \mathrm{pm}$ with stories. As he said:

Our assumption is that each event was reported in a complete standard by the reporters, sent to and edited by editors. Within four hours, or it is okay for being a little late than that, it should be ready so that it can be published within those high traffic times. This is enforced to avoid the old deadline time of print. If there isn't such a deadline mechanism, they would send [stories] around 20:00 pm. So we engineered this to meet the digital deadline while at the same time trying to excrete the old habit of print deadline (Sutta Dharmasaputra, deputy editor-in-chief, interview, January 2019).

The Editor-in-Chief of Kompas, Ninuk Pambudy, was keen to this rather conflicting values while still insisting the need to maintain Kompas' journalism standard. She stressed that being comprehensive, covering all sides, and putting the story in the right context are all no bargain issues for the culture of immediacy. Moreover, she also inserted that the 
immediacy of Kompas version are rather different from those presented by other typical online news portals that weighed more on the speed rather than accuracy.

We still enforce it [four hours deadline with comprehensive story]. So, it means that Kompas Daily, when it is trying to develop a digital environment, does not aim to compete with those online media that rely more on speed. Never thinking about or doing it. In the first place, we know that Kompas has an established journalism character. So when we become more digital, we still prioritise the standard [of comprehensiveness] (Ninuk Pambudy, editor-inchief, interview, May 2019).

This stance seems to be ambiguous as referring to practical problems encountered by journalists in the field. The new notion of speedy work flow in the digital journalism age seems to not tie up with Kompas' polished style of journalism, an essential character of the influential daily. Negotiations among the journalists in the newsroom have constantly taken place regarding the culture of immediacy as it was reflected from the reluctance behaviours of the print reporters in contributing news for digital sites. To cope with this, the editorial executives still optimised the resources within the digital division-that was restructured under the new label "general news desk" or desk berita umum/DBU-to ensure a constant and targeted 200 articles a day for kompas.id. While this seems to contradict the convergent nature, such dualism lines of production are inevitable for newsrooms adapting to the digital environment. From the perspective of newsroom innovation (Paulussen, Geens, \& Vandenbrande, 2011; Paulussen, 2016), the adoption to certain technology should be regarded as a social process-instead of a strategy or an end-goal-derived from factors like dynamic, means, and changes through destruction and re-composition to achieve adaptation.

\section{Confusion in Defining Comprehensiveness}

Observations in the newsroom revealed the fact that there were confusions among journalists in defining 'comprehensiveness' within the digital news format. As a result, they decoded comprehensiveness merely by writing cover-all-side stories in a rather 'factual journalism style' by looking at the event in one dimension from the beginning until the end. While it is true that most of the current issue stories they developed did not merely contain texts since they could be presented in multimedia format (pictures, simple graphics, and video); yet, stories within their digital site were internally criticised as still below the Kompas' very standard of comprehensive journalism style.

Antony Lee, political editor, recalled how he had problems in editing a story about terrorism that had already been published earlier in kompas.id. He needed to make some adaptation of the story to fit in with the print format for the next day's edition. Even though the online version of the stories were very long as space was not a problem, he found out that it was still lacking context. What he implied was that the reporter might have had a problem in enriching the story due to the time constraints. This is especially so after he found out that the reporter actually had all the data needed to make it more condensed and comprehensive, but did not.

The fact that the kompas.id's contents relied more on cub reporters from the general news desk/digital rather than to empower seniors but rather-reluctant reporters of print desks worsened the situation. Benediktus Krisna, an investigative reporter of the daily who 
was also assigned to back up the digital desk, stated that almost all of the reporters in the desk were lacking experience in uncovering more contexts in their stories. As he stated:

For those new reporters, I feel sympathy for them. With my respect to them, I would say that their capabilities are still within developing hard facts of $5 \mathrm{Ws}+1 \mathrm{H}$. They have not been able to identify 'what's next' of the story. They even still need to learn the context, but they are being assigned to write something premium [paywall site, kompas.id]. Well, I don't know what more to say... that's what the bosses want (Benediktus Krisna, interview, March 2019).

Fajri, a junior reporter chronicled his constraints in developing a good angle for his story about two different cases of alleged sexual harassment of underage children by their own parents, motivated by family problems and indecent rituals. While receiving early feedback from his editor that the issue was not really Kompas' type, he insisted that the story was newsworthy enough as it was a shocking case from the perspective of law and child's protection rights. Thinking very hard on shaping the crime story, he then wrote it from the perspective on how fragile a family setting could be for children to suffer from sexual violence. He stated: "At first, I was not aware that I was too vulgar by telling the details of the crime in my stories. But then I knew how I should write it. Eventually I needed to be discursive for this kind of story by setting up the frame that this crime occurred due to a dysfunctional family. My lead was more on the perspective that even a family setting was not always safe for children." (Insan Al Fajri, interview, February 2019).

Fajri's story that was published only on Kompas.id on 7 February 2019 at 20:00 PM under the title "Dua pasang Suami Istri Ditangkap Karena Cabuli Anak Sendiri [Two Married Couples Arrested for Molesting Their Own Children"] was still far from the Kompas' very standard of comprehensiveness. The frame that he was trying to convey to his readers was not strong enough although he inserted a paragraph compiling data on similar cases within the jurisdiction of South Jakarta Metro Police. Moreover, in general, the story was within only one dimension, which is a sexual crime to children, with sources ranging on police sides and the convicted persons. Further development of the story, related to other perspectives or dimensions, like child protection rights or children psychological trauma, was not explored.

\section{Immediacy for Straight News}

Most of the journalists that participated in this research realised that immediacy is something inevitable for media organisations within the digital environment. However, in its implementation for Kompas Daily, there should be certain arrangements of how it should be adapted. From the practical point of view among reporters in various beats, culture of immediacy cannot be applied to all types of reporting.

Agnes Theodora, a mid-career political reporter revealed that she was willing to comply with this immediacy reporting only for a straight news event that did not rely much on additional sources and additional data outside the spot where the news occured. As she said: "A four hour deadline after the news event can only be handled for reporting mere straight news" (Agnes Theodora, interview, February 2019). She added that covering and developing discursive issues on her newsbeat at the parliamentary building for the print was still her main priority. 
Another reporter, Laraswati Ariadne of the humanities desk, also revealed a similar thought. She said that even her editors do not require her and her colleagues to cover news for the sake of immediacy, rather, she was asked to prioritise comprehensiveness. For any humanities issue that she ran, she needed time to comprehend the context and did a thorough research in order to get the depth of the story. As she said:

I was trained by Kompas to write well. If I was asked to submit news at a rather rapid speed, what's the difference between me and reporters of Detik [online news portal that is known for its speedy but often lacking of comprehensiveness]. So my training is pointless (Laraswati Ariadne, interview, March 2019)

Deonisa Arlinta, a junior reporter, recalled how she encountered constraints as she was transferred from humanities desk to a new beat on metropolitan issues. Struggling on comprehending various kinds of issues within the desk, as well as technical concerns on multimedia reporting, she also had to deal with producing rapid comprehensive stories.

\begin{abstract}
If the issue was like murder case, we could still wrap up quickly from the police and witness statements within four hours. But as in my case of following up issues like Pisang Batu River [in Bekasi, Greater Jakarta] inundated by tons of garbage, we needed to find out data on water drainage, people;s habits, and so on... Getting on 'why' and 'what's next' of the stories are truly difficult in rapid reporting. (Deonisa Arlinta, interview, January 2019).
\end{abstract}

Her other colleague at the same desk, a cub reporter, Sucipto, also revealed that he was good enough to cover anything dealing with the straight news as most of the raw materials of the news can be gathered simultaneously at the same news spot. But this case was contrary to running news because more time was needed in order to complete his story with a more developed angle and sources. As Sucipto revealed: "But it was not easy to do the running news on the same issue, especially like me as a junior reporter, as my network is still limited" (Sucipto, interview, March 2019).

\title{
Maintaining Credibility in Breaking News and Live Report
}

As it is common in journalism, credible reports can be gained through credible sources as it enables the ability of the media to create truthful, accurate, fair, unbiased news, while at the same time protecting their organisation and audience from any error of information (Reich, 2011). Therefore, it is prevailing that media organisations are mostly relying on attribution as a way to convince the audience regarding the legitimacy of the facts that they are presented with (Franklin \& Carlson, 2011). While the practice of using unnamed sources is still common under a sparingly condition by many media (Duffy, 2014), it is not the case with the Kompas Daily. Giving no attribution for an article is considered damaging to its credibility and therefore the practice is ruled out within the newsroom.

However, during a field observation on Friday, 15 March 2019, a pressing situation emerged. The daily was left to decide which element should be prioritised: credibility or immediacy?. The editorial team was in intense discussion of whether to break news on the arrest of Romahurmuziy, the leader of the United Development Party (PPP) who is also a close Islamic ally of President Jokowi, by Corruption Eradication Commission (KPK) in a sting 
operation in Surabaya, East Java, over a bribery case. The news of the arrest first circulated among journalists at around 09:00 am from an anonymous insider source within KPK.

The daily was initially hesitant to report the arrest on kompas.id as any official information received regarding the issue was still off-the-record although many other online news portals-like detik.com-had published the stories earlier by quoting anonymous sources. Kompas.id published its first cover-all-side and concise six paragraph story on the arrest entitled "KPK Tangkap Ketum PPP, Diduga Terkait Suap Jabatan di Kemenag [KPK Arrests PPP Chairman, Allegedly Related to Bribery at Religious Affairs Ministry]" at nearly noon, at 11:59, with three sources: KPK Commissioner Agus Rahardjo, PPP's secretary general Arsul Sani, and a KPK investigator.

Lee, who was the political desk's editor in-charge for the morning planning meeting revealed the dynamic in the newsroom for tackling the issue: "I discuss this issue with Billy Khaerudin [head of general news desk or DBU/digital who is responsible for digital content of kompas.id]. He asked me of the possibility to firstly run the news for DBU [kompas.id], but since the information he got was still off-the-record, there was nothing we could do" (Antony Lee, interview, March 2019). Lee said he told Billy that the issue should further be discussed with the online desk in order to be able to plan a more comprehensive angle for its print edition.

The head of DBU/digital desk, Billy Khaerudin, admitted that the use of anonymity of sources was a sensitive issue inside the newsroom. As a senior political journalist, he recalled how this strict rule prevented him from publishing exclusive issues on the verdict of highprofile graft cases in the country. He explained that not many reporters know about the fact that a legal verdict document can be accessed through certain anonymous sources even a few days before the court trial begins. The documents revealed a lot of data that can be beneficial to reconstruct the crime and written as an exclusive as well as a leading story, even beating the online news portals. For him, using anonymous sources could still be considered and it lies to the professional judgement of reporters for determining the credibility of the sources and the issues that exert public interests. As he puts it: "So when I was still in the political desk, I was often in intense debate [regarding the use of anonymous sources]. I told [my editors] to trust their own reporters [for making discretion] for using the sources" (Billy Khaerudin, interview, February 2019).

Besides source credibility, this ethnography research also reveals the difficulty to enforce accuracy while applying live reporting. In the digital journalism environment, the use of immediacy is often intended to do first-hand or live reporting. The field observation reveals that the online edition, kompas.id, sporadically provides a feature such as live reports, giving updated information chronologically in a certain context of issue. From the intense immersion in live report activities of the daily during two sessions of Indonesian presidential candidate debate on 17 February 2019 and 17 March 2019 respectively, put forward several notions.

Kompas' live reporting was not like any other live television reporting or audio-visual reporting streamed online through social networks or internal sites. Rather, the live reporting of Kompas is merely a live blogging of a one short paragraph story and some short-clips of audio-visual footage of minute-by-minute updated information which was posted in its website. Each live report that was written by DBU (digital) reporters, will be mediated and fact-checked by a gatekeeper through CMS Silo for accuracy before being posted. From the observation, it can be highlighted that the implementation of immediacy was relatively effective to quickly disseminate updated issues. However, the quality of the gatekeeping was 
still poor as some mistakes due to inaccuracy, like mistyping, were easy to be found. Moreover, to do this live update, the newsroom only delegated reporters within the digital desk of DBU, while other reporters from the print editions, especially from the political desks, were preoccupied with their own news agenda although running on the same issue.

\section{CONCLUSION}

Being recognised as an emerging factor of today's journalism within the digital environment, immediacy continues to pose a conflicting value for conventional media that has been undergoing digital-first transformation. This ethnography of Kompas' newsroom has evidently shown that the challenge of implementing immediacy rests within the area of retaining the "so-called" ideal type of print media routines that relies on slow pace journalism to produce comprehensive pieces - as opposed to its online counterpart that has often been dubbed for practicing incomplete journalism. As a consequence, immediacy can only be achieved within a certain situation and typical format of news - straight news, that focuses on hard facts of events. The finding of the research also indicates the drive of immediacy might sacrifice the journalism value of being credible and accurate.

This ethnography finding seems to further justify the previous arguments on the culture of immediacy by Domingo (2008), Karlsson (2011), as well as Usher (2014) who put stress on the detrimental aspects of immediacy towards the pre-existing practice. The consequences that speed reporting can only be adapted modestly also appears to confirm Lim's notion on the myth of immediacy of online news that-despite being pressured by technology - is driven more by institutional and occupational routines (Lim, 2014). Clearly, all of these lead to the idea on how slow journalism (Le Masurier, 2015) as well as contextual journalism (Fink \& Schudson, 2014) can still be regarded within the digital news environment, with its long-form and multimedia story-telling format, taking journalism beyond immediate events to capture social phenomena.

Lastly, under the context of digital first transformation, the culture of immediacy remains to be in constant negotiations among all newsroom actors under the process oriented of newsroom innovation, in the sense that it is part of the dynamic for gradually excreting the old routines while shifting to the new production culture.

\section{BIODATA}

Ambang Priyonggo, MA is a PhD Candidate at the Department of Communication and Media Studies, University of Malaya. He is a lecturer at the Department of Digital Journalism, Multimedia Nusantara University (UMN), Malaysia. Email: ambang@umn.ac.id / ambang@siswa.um.edu.my

Prof. Hamedi Mohd Adnan is a senior lecturer at the Department of Communication and Media Studies, University of Malaya. Email: hamedi@um.edu.my 


\section{REFERENCES}

Anggoro, A. S. (2012). Detikcom: Legenda media online. Jakarta: Buku Kita.

Boczkowski, P. J. (2004). Digitizing the news: Innovation in online newspaper. Cambridge: MIT Press.

Boczkowski, P. J. (2010). News at work: Imitation in an age of information abundance. Chicago: The University of Chicago Press.

Braun, V., \& Clarke, V. (2006). Using thematic analysis in psychology. Qualitative Research in Psychology, 3(2), 77-101.

Buhl, F., Günther, E., \& Quandt, T. (2019). Bad news travels fastest: A computational approach to predictors of Immediacy in digital journalism ecosystems. Digital Journalism, 7(7), 910-931. https://doi.org/10.1080/21670811.2019.1631706

Castells, M. (2009). Communication power. New York: Oxford University Press Inc.

Crang, M., \& Cook, I. (2007). Doing ethnographies. London: Sage.

Domingo, D. (2008). When immediacy rules: Online journalism models in four Catalan online newsrooms. In D. Domigo, \& C. Paterson (Eds.), Making online news: Newsroom ethnography in the second decade of internet journalism (pp. 113-126). New York: Peter Lang Publishing Inc.

Duffy, M. (2014). Anonymous sources: A historical review of the norms surrounding their use. American Journalism, 31(2), 236-261. https://doi.org/f8j2

Fetterman, D. M. (2010). Ethnography: Step-by-step. London: Sage.

Fink, K., \& Schudson, M. (2014). The rise of contextual journalism, 1950s-2000s. Journalism, 15(1), 3-20. https://doi.org/10.1177/1464884913479015

Franklin, B., \& Carlson, M. (2011). Journalist, sources, and credibility: New perspectives. New York: Routledge.

Gobo, G. (2008). Doing ethnography. London: Sage.

Hill, D., \& Sen, K. (2005). The Internet in Indonesia's new democracy. London: Routledge.

Hill, D., \& Sen, K. (2011). Politics and the media in twenty first century Indonesia: Decase of democracy. London: Routledge.

Karlsson, M. (2007). Immediacy of online news: Journalistic credo under pressure. Proceedings of International Communication Association (ICA) Annual Meeting.

Karlsson, M. (2011). The immediacy of online news, the visibility of journalistic processes and a restructuring of journalistic authority. Journalism, 12(4), 279-295. https://doi.org/10.1177/1464884910388223

Le Masurier, M. (2015). What is slow journalism? Journalism Practice, 9(2), 138-152. https://doi.org/10.1080/17512786.2014.916471

Lewis, J., Cushion, S., \& James, T. (2005). Immediacy, convenience or engagement? An analysis of 24-hour news channels in the UK. Journalism Studies, 6(4), 461-477. https://doi.org/10.1080/14616700500250362

Lim, J. (2012). The mythological status of the immediacy of the most important online news: An analysis of top news flows in diverse online media. Journalism Studies, 33(2), 7189.

Lim, M. (n.d.). @crossroad: Democratization \& corporatization of media in Indonesia. Tempe: Ford Foundation and Participatory Media Lab at Arizona State University. https://cspo.org/library/crossroads-democratization-and-corporatization-of-mediain-indonesia/ 
Lim, M. (2005). @rchipelago online: The internet and political activism in Indonesia. Ennschede, The Netherland: University of Twente.

Lim, M. (2012). The league of thirteen: Media concentration in Indonesia. Research report. Tempe: Ford Foundation and Participatory Lab at Arizone State University.

Lubis, M. (2017, July 26). Tren baru di kalangan pengguna internet di Indonesia. Nielsen press room article. https://www.nielsen.com/id/en/press-releases/2017/TREN-BARU-DIKALANGAN-PENGGUNA-INTERNET-DI-INDONESIA/

Manan, A. (2018). Ancaman baru dari digital. Laporan Tahunan AJI 2018. Jakarta Selatan: Aliansi Jurnalis Independen (AJI).

Margianto, H. (2017). Kompas.com: Transformasi digital Kompas. Jakarta. https://vik.kompas.com/sejarah-kompascom/

Nugroho, Y., Putri, D., \& Laksmi, S. (2012). Mapping the landscape of the media industry in contemporary Indonesia. In, Enganging media, empowering society: Asseing media policy and governance in Indonesia through the lens of citizens' rights. CIPG \& HIVOS.

Oetama, J. (2001). Pers Indonesia: Berkomunikasi dalam masyarakat tidak tulus. Jakarta: Penerbit Kompas.

Omar, B. (2017). Online news production, consumption and immediacy: The remediation perspective. Jurnal Komunikasi: Malaysian Journal of Communication, 33(3), 250-266. https://doi.org/10.17576/JKMJC-2017-3303-15

Paulussen, S. (2016). Innovation in the newsroom. In T. Witschge, C. Anderson, \& A. Hermida (Eds.), The Sage handbook of digital journalism (pp. 192-206). London: Sage.

Paulussen, S., Geens, D., \& Vandenbrande, K. (2011). Fostering a culture of collaboration: Organizational challenges of newsroom innovation. In D. Domingo, \& C. Paterson (Eds.), Making online news: Newsroom ethnographies in the second decade of internet journalism (pp. 3-14). New York: Peter Lang.

Priyonggo, A., \& Wijaya, L. (2013). Press as an agent of restraint: The political roles of Indonesian press against corruption [conference presentation]. The Fifth Conference of Communication Industry and Journalism Education in Digital Age-Chinese Culture University, Taipei.

Reich, Z. (2011). Source credibility and journalism. Journalism Practice, 5(1), 51-67. https://doi.org/10.1080/17512781003760519

Saltzis, K. (2012). Breaking neews online: How news stories are updated and maintained around-the-clock. Journalism Practice, 6(5-6), 702-710. https://doi.org/ggw4j9

Schumacher, A., Sihn, W., \& Erol, S. (2016, October). Automation, digitization and digitalization and their implication for manufacturing process [conference presentation]. International Scientific Conference. Bucharest, Romania.

Sen, K., \& Hill, D. (2000/2007). Media, culture, and politics in Indonesia. South Melbourne: Oxford University Press.

Sen, K., \& Hill, D. (2007). Media, culture, and politics in Indonesia. South Melbourne: Oxford University Press.

Sudibyo, A. (2014). Ekonomi politik media penyiaran. Jakarta: Institute for Study of the Free Flow of Information (ISAI) and Institute for Islamic and Social Studies (LKiS).

Tapsell, R. (2014). Platform convergence in Indonesia: Challenges and opportunities for media freedom. Convergence: The International Journal of Research into New Media Technologies, 21(2), 182-197. 
Tapsell, R. (2017). The political economy of digital media. In E. Jurriëns, \& R. Tapsell (Eds.), Digital Indonesia: Connectivity and divergence (pp. 56-71). Singapore: ISEAS-Yusof Isha Institute.

Tong, J., \& Lo, S.-h. (Eds.). (2017). Digital technology and journalism: An international comparative perspective (Introduction). Cham, Switzerland: Palgrave Macmillan.

Usher, N. (2014). Making news at the New York Times. Michigan: University of Michigan Press.

Usher, N. (2017). Breaking news production process in US metropolitan newspaper: Immediacy and journalistic authority. Journalism, 19(1), 1-16.

Zeller, F., \& Hermida, A. (2015). When tradition meets immediacy and interaction: The integration of social media in journalists' everyday practices. Sur le journalism, Sobre Jornalismo, 4(1), 106-119. 